\title{
Complementary Effects of Agricultural Tourism and Tourist Destination Brands in Preserved Scenic Areas in Mountain Areas of China and Europe
}

\author{
https://doi.org/10.1515/opag-2019-0050 \\ received April 26, 2019; accepted August 13, 2019
}

\begin{abstract}
Many scenic areas in mountain regions have attained preservation status, which enhances strategies to attract tourists based on its unique natural or cultural resources and its original brand. It is a particular challenge for plant-dependent assets how tourist attraction for the scenic areas could be increased in the off-season, taking account of the strong seasonal fluctuations. The paper focuses on lessons from a specific case of preserved scenic area, the area of rhododendron ("Dujuan" in Chinese) and compares it with several European examples. As indicated in the denomination of "Baili Dujuan" Scenic Area, a National Park in Guizhou Province in China, this plant is the leading asset in that area. The characteristics of the seasonal flowering of rhododendrons causes Baili Dujuan serious problems of a seasonal tourist offer. For several years Baili Dujuan has been promoting complementary activities of agricultural tourism and developing a brand of flower-enjoying destinations, by supporting the local farmers to grow also other economic flowers and fruit trees that bloom in different seasons. Such instruments have contributed to extend the flow of tourists for longer periods of the year, generating also substantial benefits to farmers and other local industries. Based on the emerging initiatives in Baili Dujuan and interesting experiences from protected mountain areas in Europe, the complementary effects of agritourism and tourist destination brands in Preserved Scenic Areas will be explored for further development.
\end{abstract}

Keywords: Preserved scenic area; Tourist destination brand; Baili National Park; Rhododendron park; Local attractiveness

\footnotetext{
*Corresponding author: Thomas Dax, Federal Institute of Agricultural Economics, Rural and Mountain Research (BAB), Vienna, Austria, E-mail: thomas.dax@bab.gv.at

Yanying Chen, Guizhou University of Engineering Science, China Dachang Zhang, Water and Eco Crisis Foundation, San Jose, CA, USA
}

\section{Introduction}

Agritourism has grown to an increasing tourism type in many countries of the world. Even if such farm stay experiences are more widespread in countries which have developed intensive linkages of non-farming population with farm structures over many decades (Potočnik-Slavič and Schmitz 2013), more recently always everywhere respective initiatives are emerging (Sznajder et al. 2009). These linkages might be a consequence of farm structure adaptation and demographic changes leading to out-migration from rural areas. Nevertheless, emotional ties and desire for nature and farm experience remained a strong incentive, and even seem to have increased, within urban population, contributing to the recent revival of the search for agritouristic encounters, rising demand for agritourism in many regions and valuation of this specific tourism type. The origin of first organized farm stays date back to the $19^{\text {th }}$ century and have particularly often occurred in mountain areas of Italy, Austria and the Alps (Santucci 2013). However, as comparative reports on the practice of agritourism around the world argue (Embacher 1994; McMahon 1996; Hall 2004; Sznajder et al. 2009; PotočnikSlavič and Schmitz 2013; Lupi et al. 2017) they have spread meanwhile to almost all rural areas. According to divergent regional and farm characteristics the organization, services offered and demand for agritourism developed very differently between different countries.

Besides those farm units building their specific attractions on the affinity to livestock available at the farm or experiences with farm work, farms in scenic areas largely based their appeal for tourists also on landscape, environmental quality, tranquility and emotion (Lu et al. 2017), which is tied to less densely populated areas. Relevant amenities represent valuable assets for agritourism, based particularly tight on natural and cultural heritage (LaPan and Barbieri 2013; Khamung 2015). Various disciplines have explored challenges for rural development and agritourism addressing influential aspects of different spatial scales and natural, social, cultural and eco- 
nomic influences. While agritourism activities often arise from a notion of "rural idyllic" places (Shucksmith 2018) the reality of most rural regions has shifted (Copus et al. 2011). However, destination management is largely based on affect theory and the concept of 'atmosphere' (Brown et al. 2019), including aspects of aesthetics and emotions (Griffero 2014) which suggest unique experiences to be encountered through agritourism practices. The growing interest in food niche markets, food origin and quality (Sidali et al. 2015, Ermann et al. 2018), culinary heritage and culinary tourism (Slocum and Curtis 2018) added to the increasing attention for rural lifestyles and nature experiences. Preservation aspects for scenic landscapes are therefore core for such strategies. This situation is not just beneficial as with growing tourism intensity tensions between preservation needs and tourism development options increase, implying a field of open and hidden conflicts between (small) farm tourism developers aiming to preserve specific land resources and local institutions and stakeholders pushing for accelerated "growth" strategies (Wang and Yatsumoto 2019).

Within these general trends, farm stays are an ideal means to offer contact with agricultural practices, livestock and nature experience which is increasingly missed by urban people (Streifeneder 2016). The diversity of understanding of agritourism results from substantial differences in land management systems, agricultural structures, settlement and economic systems, and cultural legacies. Studies to define agritourism highlighted the "agricultural setting", the aspect of "entertainment", the organization and activities of the "farm" and "education" of farm household members as crucial elements for assessing agritouristic characteristics (Gao et al. 2013). In differentiating agritourism from broad concepts of "rural tourism" it seems important that agritourism also includes staged and authentic activities which are often related to specific landscapes and preservation areas. As rural tourism in China has undergone a rapid development over the last decades (Wang et al. 2013) this paper focuses on an example of a preservation area in China that highlights a specific plant and the preserved area of its origin. It then compares the development of the agri-touristic offer in that area with more traditional forms of linking agri-tourism in several European regions with similar attractive features. Agritourism has been analysed as an important diversification activity of farming in developed countries (Barbieri et al. 2008) contributing to increased farm income and alleviating economic difficulties of farm households. It is also suggested that agritourism is conducive to socio-cultural and environmental benefits, supporting sustainable pathways in local development (Barbieri 2013). Implica- tions are particularly relevant for preserving landscape features of high appeal to tourists (Gao et al. 2014) and branding appears as a pivotal approach for agritourism based on the experiences through recreation on farms providing "memorability, distinctiveness, relevance and flexibility" (Barbieri et al. 2016). According to the definition used by the National Tourism Bureau (2002) in China, the so-called agritourism refers to the tourism activities mainly through the agricultural production process, rural features, and farmers' work and life scenes. It is the general designation of the tourism industry that combines agriculture and tourism, and makes use of agricultural landscape, food and rural space to attract tourists to visit and provide special services for tourists.

This combination of activities will be explored on the emerging initiatives in Baili Dujuan (Rhododendron) Scenic Area, a National Park in Guizhou of Southwest China, and selected interesting experiences from European mountain protection areas. In these contexts, unique natural and cultural tourism resources are core elements for building the original brand of preserved scenic areas as tourist destinations. In contrast to overarching economic trends, preserved scenic area development is based on the protection of natural resources which determine the development and utilization in such preserved areas, oriented not only on economic efficiency criteria. Many preserved scenic areas mainly rely on the valuation of its attractiveness, by raising income from entrance fees to maintain their usual, day by day operation. It is a goal of the preserved scenic areas to increase rational strategies and utilization of the specific assets, add tourist attraction in the off-season, generate multiple economic profits beside the income from entrance fees, and realizing mutual benefits for the tourists to scenic areas and tourist destination stakeholders.

Preserved Scenic Areas (PSA) can be understood as a regional complex composed of tourist attractions, supporting facilities and services. According to its varying functions, goals and management approaches, the scenic area is divided into economic-developing and preservation areas. While the economic-developing areas include theme parks and resorts, the core areas of the PSA, the preservation part, include scenic spots, forest parks, nature reserves and historical-protected units (Xu 2008).

Addressing specificity of places as valuable for preservation and branding of commodities in general focuses on a process that tries to articulate, integrate and enhance attributes embodied and connected in brands in meaningful and valuable ways" (Pike 2015, 5). With rising consumer-orientation of the current economy, society and polity brands proliferated and embrace all economic activities. 
This meant that also for tourism development an increasing complexity can be observed. Tourism destination branding builds on previous consideration of the crucial relevance of "origin" and suggestions "that destinations are arguably the travel industry's biggest brands" (Pike 2005, 2). Any effective destination marketing organization (DMO) would therefore seek ways to raise perception of the target area (in our case the preserved scenic area) within consumers, i.e. tourists. Quite often the DMO designs a brand through expanding the place name or uses a slogan for public articulation of a destination's brand strategy. With regard to agritourism activities it seems crucial that tourist destination marketers understand the actual perception of a destination held by the main target market, and determine whether the brand they wish to launch is consistent with the perception of the customer market. Some consumers' actual impression of the tourist destination is greatly different from the self-brand designed by the tourist destination, and there is a problem of brand deviation (Shao 2012). It seems crucial to avoid such a gap in strategy building of agritourism.

The paper will be organized as follows: After this introduction section 2 will focus on the core role of Preserved Scenic Areas to promote Tourism Destination Image which will be followed by an account on the contribution of agritourism towards TDI creation. The center of the article is the presentation of the case study in China, highlighting the challenges and potential of PSA which will be then supplemented by a section showing four selected comparable cases from European mountain regions. Finally, the discussion section will summarize the key lessons learnt from the diversity of these cases and their contribution towards TDI shaping as well as place-specificity in agritourism practical development.

\section{Preserved Scenic Areas as promoters of Tourism Destination Image}

It is of main influence that the perception of the tourist destination by tourists is captured in the Tourist Destination Image (TDI). During travel planning, tourists usually learn about the tourist destinations that are attractive to them through such contacts and information by friends, relatives, colleagues, newspapers, books, TV and online media, and make choices and plans according to their time, economic status and preferences. After a trip, the tourists will, intentionally or unintentionally, make a comprehensive evaluation of the landscape, service and facilities of the tourist destination based on their own experience. On this basis, the positive or negative image of the tourist destination will determine whether they will visit again or recommend to others. Selby and Morgan (1996) believe that tourists' original image is composed of organic image and induced image. The former is derived from popular culture, media, literature, education and other channels not directly related to tourism. The latter is derived from guidebooks, advertising and other tourism business channels. Following Baloglu et al.'s (1999) division of the perceived image of tourists into cognitive image and affective image it becomes apparent that the latter achieves particular relevance in tourist types closely linked to emotion and personal experiences. Though different, they are all based on the "perceived image" of tourists (Wen et al. 2009).

This is particularly influential for a preserved scenic area (PSA) which attracts tourists with its unique natural or cultural resources as its original image, but it also has many shortcomings. Different from economic-developing scenic areas, PSAs give priority to resource protection which needs specific input funds. In particular, many natural resource-based scenic areas are located in remote locations and have inconvenient transportation. To enhance accessibility of the scenic areas for tourists, essential roads and infrastructure construction must be provided, which requires a large amount of capital. In some scenic areas, ticket prices have been raised substantially, which has created a bad image of "excessively high costs" for tourists (Guo \& Dong 2010). Some scenic areas, due to their strong seasonal tourism products, have to face a problem of excessive amounts of tourists with regard to the service capability during the peak season and a large number of facilities are idle during the off-season. It is hence a crucial issue how to make full use of the core scenic attractions and the brand effect, while thriving at the same time to protect the resources. Moreover, the use of abundant tourism products during off-seasons, and improving services to attract tourists during the off-season is a big challenge for the sustainable development of scenic tourism. Therefore, it is of great significance to form a mutually beneficial situation and wide enough scope of activities for all stakeholders of scenic areas, tourists and tourist destinations, and to improve the PSA's TDI. 


\section{Analysing the contribution of Agritourism to Improving TDI}

\subsection{Roles of Agritourism in Improving PSA's TDI}

The complexity of destination branding requires a large variety of actors to contribute and collaborate in TDI formation, particularly within a PSA context. The interest here is on agritourism's contribution and specific tasks in this process. The main aspects addressed below underpin the role in enriching TDI, raising benefits, enhancing experiences, and extending agritourism activities towards off-seasons.

According to the characteristics of agricultural production such as seasonality and flexibility, strategies are required that choose the featured crop varieties which would present the best sightseeing landscape in the off-season of the preserved scenic area. For example, rape planting is successfully combined with the local sightseeing widely experienced in China (Zhang 2017). China's vast land area and diverse climatic conditions result in that the blooming periods of rapeseed flowers vary in region and time and the tourists can enjoy the beauty of rapeseed flowers simply following its appearance.

Agritourism can bring good economic benefits by extending the PSA's peak season. Only in one region, the Jiangxi Province, in March 2017 about 1 million of tourists were guided to the beauty of rapeseed flowers by travel agencies, and the total number of people who visited the rape fields there reached about 4 million. The data of British tourism and agricultural development during the period from 1990 to 2015 explored a long-term and balanced relationship between British tourism and agriculture, indicating that every $1 \%$ increase of British agricultural added value followed an increase of $0.6721 \%$ of tourism income (Lin and Qiao 2017).

Agritourism is an organic combination of agriculture and tourism, production and consumption, work and leisure. It not only provides tourists with the opportunity to appreciate the agricultural landscape, but also the experience of participating in the process of agricultural production, such as planting and picking. The transformed rural hotels or restaurants can provide tourists accommodation and foods by the famers' residential houses. The fresh vegetables directly from the farmers' gardens, and the meat or fish groomed by the farmers are always the most popular experience with tourists. In addition, green agricultural products or local products are popular commodities for tourists or gifts for relatives and friends. Agritourism can extend the tourists' stay in the tourist destination, which is conducive to improving the service contents, improving the service quality and improving the service image of the tourist destination.

If there are not sufficient visitors, the destiny of a tourist destination is to shut down services. Well-designed agritourism facilities can attract tourists to the destination also in off-seasons. A minimum amount of tourists in each season can guarantee the normal business and service quality of hotels, restaurants, rural entertainment and tourism commodity, which is conducive to sustainable development of tourism and tourism related industry of the area. The tourists' perception of the seasonal image of the tourism destination of the -preserved scenic area will consequently also change towards the recognition of the tourism image over the whole season.

\subsection{Closing the circle: Use enhanced TDI to promote agritourism}

The improvement of the image of the tourism destination of the preserved scenic area will attract more tourists to visit, experience leisure, and involve shopping (particularly from involved farms). Tourists' consumer demands will bring more opportunities to the development of agricultural tourism, increase the agritourism revenue, provide good entrepreneurial and employment opportunities for the local residences, and promote the integrated development of the first, second and third industries. During the development, farmers would adapt their family owned restaurants and hostels, or invest land or capital to establish the agricultural cooperatives or companies for characteristic planting/aquaculture and deep processing of agricultural products for increasing the added value of agricultural products and developing local products and tourism commodities. Some farmers become the legal representatives of cooperatives or companies, some farmers become the employees working for cooperatives or agricultural companies after transfer of their land, and others enter the service industry as waiters or managers (Li 2017).

\section{Presenting a specific case of PSA}

\subsection{The Baili Dujuan Scenic Area, Guizhou, China}

The Baili Dujuan Scenic Area is presented as a specific case to illustrate and analyse aspects for agritourism 
development in PSA. It is located in the hinterland of Wumeng Mountains, Guizhou Province, China, covering 56 villages and an area of $485 \mathrm{~km}^{2}$ (belonging to the four townships of Jinpo, Pudi, Renhe, Dashui, and the two districts of Pengchen and Jiamu). This area is inhabited by 21 different nations, such as Han, Yi, Miao, Bai, Man, Buyi, Gelao, Dong and other more, with a total population of more than 100,000, among which 57\% belong to ethnic minorities. It is a karstic hilly landform on the Guizhou Plateau, under the warm temperate humid monsoon climate, with an annual average temperature of $11.8^{\circ} \mathrm{C}$ and a summer average temperature of $19^{\circ} \mathrm{C}$. In this area about 220,000 ha is cultivated, with a particularly high share of forest coverage of $59.3 \%$. Its air quality is up to the national standard with an average content of negative oxygen ions more than $69,000 / \mathrm{cm}^{3}$.

Baili Dujuan Scenic Area was established in 1987. The core natural landscape is the primeval forest of rhododendron, the only park area of this type in China, stretching over $125.8 \mathrm{~km}^{2}$. There are more than 60 species of rhododendrons, accounting for six out of nine subgenera of the world's rhododendrons. A variety of rhododendron bloom in spring, their flowers lasting several weeks, and cover the mountains. Beili Dujuan is organizing the Rhododendron Festival from March to May every year. The opening ceremony of the Festival is arranged in general at the period when about a quarter of rhododendrons bloom. The news media, travel agencies and special guests are invited to the ceremony, and visitors are attracted to enjoy the flowers in the PSA. Due to the attractive asset and the festival organization, the Baili Dujuan area has won numerous awards in the last 20 years and its tourist destination image has been continuously improved (Table 1).

The tourists' comments on the major tourism networks show that the tourists are highly satisfied with the flower landscapes. There are some expressions, such as "original ecology", "great beauty", "too spectacular", etc. frequently used by tourists. One girl said, "it's so beautiful that at the moment seeing a big piece of flowers, my heart suddenly calmed down, there was a kind of desire to get married". "Awesome! Amazing!" said a visitor who came at the end of the flower season. "It was a pity that I went to Beili Dujuan almost off season, but I will be there in time next year. Though only single way driving from Sichuan to Beili Dujuan is about $800 \mathrm{~km}$, that is worth it!” Another quote says, "Recently Beili Dujuan has a good tourism outlook with many more projects and investments in catering as it is a good place for enjoying flowers in spring, escaping from the summer heat, relaxing in autumn, and maintaining a healthy ambiance in winter. Everything is at the sound of nature, with so fresh air. It's better to go there when you're in a good or bad mood. Hi, relax yourself in Beili Dujuan, meet your new spirit!”

\subsection{Agritourism enhancing and benefitting from TDI}

While the PSA has developed since more than two decades, the scenic area has intensified its efforts to improve its tourism destination image to promote the local economic construction with the agricultural tourism industry at its core particularly over the last five years.

\subsubsection{Transformating traditional agriculture}

Local traditional agriculture mainly produces corn, soybeans, red beans, wheat, potatoes and other crops, and the main economic crop is tobacco. In recent years, as the planting area of tobacco has been required to shrink year by year, agriculture is facing restructuring. At the same time, due to a large number of young and middle-aged people having migrated for work to cities, there is not enough labor for agriculture, plus the dispersed farming plots and traditional production methods make land use unable to achieve good economic benefits. On the other hand, agricultural transformation is required to meet the various needs of tourists and the development of the tourist destinations. Thus, with the encouragement of the government, villages have established many planting/ breeding cooperatives or companies to plant a variety of economic crops, fruits and herbal medicines, develop animal husbandry and tourism services, combine agriculture with tourism, transfer land for intensive management, accelerate leisure agriculture and tourism agriculture in accordance with the requirements for creating leisure and recreational destinations. Farmers can transfer land to cooperatives and collect the land transfer fees every year. They can also contribute their funds or land (according to national land acquisition price) to become the shareholders. At the same time, they can work with a cooperative/company and receive wage income. The integration of the first, second or third industries in Beili Dujuan thus becomes increasingly strong.

\subsubsection{Expanding the TDI and Promoting services in the scenic area}

The scenic area of Beili Dujuan is currently composed of Dujuan (rhododendron) Flower Zone, Pudi Spot, Jinpo 
Table 1: Timeline of Beili Dujuan Scenic Area development (Source: Baili Rhododendron Administration Tourism Bureau, 2018)

\begin{tabular}{|c|c|c|}
\hline Year & Approval Authority & Award \\
\hline 1987 & Guizhou Provincial Government & Top 10 Scenic Attractions in Guizhou \\
\hline 1993 & China National Forestry Administration & Baili Dujuan National Forest Park \\
\hline 2007 & Guizhou Provincial Government & Nature Reserve of Guizhou Province \\
\hline \multirow[t]{4}{*}{2010} & $\begin{array}{l}\text { Jointly named by the embassies in China and the Organiz- } \\
\text { ing Committee of Talent Competition of the ambassadors \& } \\
\text { madame in China }\end{array}$ & $\begin{array}{l}\text { The Excellent Ecological Tourism Destination of China Most } \\
\text { Recommendable to the World }\end{array}$ \\
\hline & The Sixteenth Golden Travel Award of Asian Tourism & The Most Internationally Renowned Attraction in 2010 \\
\hline & The Sixteenth Golden Travel Award of Asian Tourism & $\begin{array}{l}\text { Ten Natural Eco-Tourism Tourist Attractions in Asia and Greater } \\
\text { China }\end{array}$ \\
\hline & $\begin{array}{l}\text { China National Tourist Attractions quality evaluation Commit- } \\
\text { tee }\end{array}$ & 4A National Tourist Attraction \\
\hline 2011 & $\begin{array}{l}\text { Ministry of Human Resources and Social Security of the Peo- } \\
\text { ple's Republic of China and CNTA }\end{array}$ & National Advanced Collective of Tourism System \\
\hline 2012 & Jointly named by the embassies in China & $\begin{array}{l}\text { The Most Recommendable World's Largest Natural Rhododen- } \\
\text { dron Garden }\end{array}$ \\
\hline 2013 & $\begin{array}{l}\text { China National Tourist Attractions quality evaluation Commit- } \\
\text { tee }\end{array}$ & 5A National Tourist Attraction \\
\hline 2014 & $\begin{array}{l}\text { CNTA、China National Environmental Protection } \\
\text { Administration }\end{array}$ & National Eco-Tourism Demonstration Area \\
\hline \multirow[t]{3}{*}{2016} & $\begin{array}{l}\text { China National Tourism Administration of the People's Repub- } \\
\text { lic of China }\end{array}$ & $\begin{array}{l}\text { The Establishment Unit of The Demonstration Area for Tourism } \\
\text { Throughout the Whole Region }\end{array}$ \\
\hline & China National Tourism Administration (CNTA) & $\begin{array}{l}\text { National “Tourist Attractions Help Villages” Demonstration } \\
\text { Project for Poverty Alleviation with Tourism }\end{array}$ \\
\hline & $\begin{array}{l}\text { Ministry of Agriculture and Rural Affairs of the People's Repub- } \\
\text { lic of China }\end{array}$ & $\begin{array}{l}\text { National Leisure Agriculture and Rural Tourism Demonstration } \\
\text { Zone }\end{array}$ \\
\hline \multirow[t]{2}{*}{2017} & Jointly named by the embassies in China & $\begin{array}{l}\text { The Excellent Tourism Destination of China Most Recommend- } \\
\text { able to the World }\end{array}$ \\
\hline & 2017 China Travel Brand Festival & $\begin{array}{l}\text { Top } 105 \text { A Scenic Brands Recommended to Tourists Around the } \\
\text { World }\end{array}$ \\
\hline 2018 & $\begin{array}{l}\text { International Leisure Economic Promotion Association, China } \\
\text { City Travel Magazine、China Travel Media Alliance }\end{array}$ & China's Best Health and Leisure Tourism Area \\
\hline
\end{tabular}

Spot, Beili Dujuan Prairie, Jiamu Spot, Lake Beili Dujuan, and MIdI River. To fully integrate the core scenic spots with non-core scenic resources, and to break the seasonal barriers to tourism, Beili Dujuan vigorously develops various types of agritourism to increase offer also in off-seasons.
Agritourism has transformed traditional agriculture. Local traditional agriculture is the base for the excellent tourist destination image of Baili Dujuan which attracts millions of tourists, provides local farmers with good opportunities to participate in the maintenance of scenic natural landscapes, facilities improvement, safety, clean- 
ing, services etc., and greatly stimulates the business and employment markets in dining, accomodation, shopping, artefact/souvenir produce, and entertainment. The relocation of immigrants due to landscape creation, ecological protection, road and new town construction, old house renovation becomes the boosting factor for the expansion and upgrading of the service industry in Baili Dujuan. Now the first two phases of the creation project of Huahai Cultural City has been completed, and 532 households of immigrated people have been settled into a new settlement named "Shiniu (stone cattle) Tourist Town". All single-houses in the new town use a standard design, 4-story, total living space of about $320 \mathrm{~m}^{2}$ offering attractive space for tourism facilities. In addition, the overall cultural landscape, reception capacity, service, environmental quality and sanitation quality of the whole scenic area have been also greatly improved.

Agritourism development has also expanded the local TDI. The scenic area of the Baili Dujuan Park has only 5 administrators, with about 200 staffs for management and services regularly. During the Rhododendron Festival, a large number of temporary service personnel are needed. Through cooperation with universities such as Guizhou Minzu University, students in tourism management-related master studies can do their interns of management studies during the Festival, and solve the problem of insufficient administrative personnel during the festival. In addition, during the Festival, a large number of temporary workers are recruited for meeting the needs of security and cleaning services. These administrative and service personnel are well trained and their good service attitude has been well received by tourists.

\subsubsection{Accessibility and infrastructure development}

Baili Dujuan has excellent external transportation facilities now. Hangrui Expressway, Qianda Expressway, Guibi Expressway and Guibi Highway pass through. It is about 40 km, 100 km, 140 km and 150 km from Feixiong Airport of Bijie, Xinzhou Airport of Zunyi, Guiyang North Railway Station and Longdongbao Airport of Guiyang, respectively. With the acceleration of the construction of Chenggui Express Railway and Zhaoqian Railway, Baili Dujuan will become more and more convenient for external transportation. Shortening the traveling time from dozens of hours to several hours will enable more and more people from all over the country to come here much more easily. The mountains are no longer obstacles for traveling, but the most beautiful sceneries along the road.
More than 3 billion CNY (about 461.5 million USD) has been invested to build more than $190 \mathrm{~km}$ of tourist roads and 6 parking lots of about $50,000 \mathrm{~m}^{2} .53 \mathrm{~km}$ of trails have been rebuilt with $48 \mathrm{~km}$ of new trails. There are 22 tourist shuttle bus stations, 60 tourist and sightseeing vehicles, more than 1,700 scenic signs and more than 800 garbage bins. One large exhibition hall and a leisure tea house have been built. Eight core attractions have been upgraded with 24 new sightseeing spots.

Efforts have been made to rectify the "dirty and messy" environment and sanitation. The organic integration of infrastructure construction and beautiful natural scenery is under consideration. There are four new Yi-style towns and ten characteristic tourism demonstration villages, plus cultural activity plazas, libraries, and cultural corridors in the villages. The new constructed special ecological parks such as a camellia garden, a cherry-blossom garden, a wintersweet garden and a rhododendron landscape garden are open to tourists and an alpine sports park is under construction. All these infrastructure improvements will add to the agritourism offer and raise TDI of Beili Dujuan.

\section{Comparative cases from European mountain areas}

Albeit the case presented through the "Baili Dujuan" Scenic Area, a National Park in Guizhou Province in China (flowering of Rhododendron) is a particularly insightful one, there are numerous examples throughout Europe where agritourism initiatives are based on specific flowers or fruits, with an exceptional iconic value and image for the specific mountain region. All have in common that they address the uniqueness of the plants appearance and the short flowering season within the year. It is hence a particular challenge to increase yearround attractiveness and options for tourism activities for longer periods and enable a year-round tourism involvement. To provide several cases and specific features from European experiences several selected examples should be briefly presented here. The main criteria for inclusion is their long-term experience with agritourism activities in a mountain context, based on a particular set of plants to attract visitors. Examples are taken from various parts in the Alps (Italy, France, Austria) and the Balkans (Bulgaria) to underpin the relevance of the theme in different geographical parts of Europe. They also should set the scene for different approaches in making use of botanical 
resources for agritourism development and TDI in mountain regions.

\subsection{The Gran Paradiso National Park (Italy)}

This national park is one of the main preservation areas in the Alps in Europe. Besides its many conservation aspects, it is interesting to mention the specific focus on botanical resources closely linked to mountain flowers. The park provides activities on "botanical" education through its "Paradisia Alpine Botanical Garen" and three specific visitor centers in the area (The Fondation Grand Paradis 2018). It provides a privileged space for making a close connection of tourists with nature and supports learning through workshops and guided activities. Created in 1955 and located at a sea level of more than 1,700 metres, the garden contains about 1,000 different species of plants and flowers from the Alps and the Apennines, as well as some examples of vegetation from other mountain ranges around the world. It enhances the opportunity for visitors to explore and observe these plants and provides also learning facilities to experience and respect the alpine flora.

\subsection{Lavender farms in the Provence-Alpes- Côte d'Azur region (France)}

Even lavender production is not unique to France, its best known location is the region of Provence in Southern France. Figure 1 indicates the areas of highest density of lavender and those areas east of Avignon which are particularly often visited in the flowering season being generally from mid-June to early July (FarmStayPlanet 2018). Visitors can learn more on the plant and its local production through the Museum of Lavender in a small village of Cabrières d'Avignon, visit a Cistercian abbey, participate in several lavender festivals, but also visit farms and processing units. Such guided farm tours contribute to increase local revenue and to make tourists also stay longer in the area.

\subsection{The Valley of Roses (Bulgaria)}

The Valley of Roses in Bulgaria is another very well-known example where a specific flower is responsible for the image and the main attraction and perception of a specific (mountain) region (RoseFestivalKazanlak.com 2018). This flower has a long history with its origins as far as Ancient
Persia and "modern" production of high quality rose oil starting in Bulgaria in the 17th century. Since that time, rose oil has impacted the livelihood, culture, and traditions of Bulgarians living in the southern sub-mountain region of the Balkan Mountains which made the valley known widely as 'The Valley of Roses'. Production in this place depends on climate characteristics and thanks to the specific climate circumstances for Rosa Damascena boosts over 280 different types. About 500 farmers in the area are involved in the production, using specific methods of maintaining, planting and processing the rose petals, according to different rules in each of the villages. Again the blooming season is limited to the period from about Mid-May to Mid-June providing a highly seasonal attraction. Festivals and the appreciation of important cultural changes due to the planting, processing and presenting of the flower are important aspects of this example of agritourism activity. A comprehensive guide is available to explain the heritage background of the Rose Festival in the region and enable encounters of tourists with rose producers and experience the rich heritage involved with it.

\subsection{The valley of the cornel cherry (Austria)}

Based on the cornel cherry (Cornus mas) production a whole valley in the low mountains of Austria has elaborated a common regional strategy to make use of that plant and initiated a series of linked local and regional activities (Regionalplanungsgemeinschaft Pielachtal 2008). The production of the cornel cherry is taken as the cornerstone for establishing the regional identity of the valley and has inspired local action to cooperate in local activities for improving value added provided through the

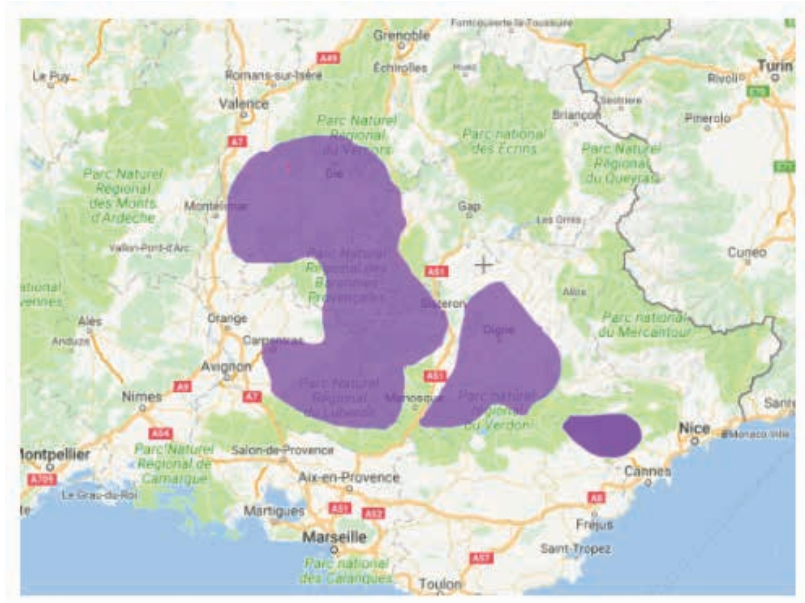

Figure 1: Rough approximation of best areas to see lavender fields 
production, processing and linking the appearance of this plant to local tourism attractions. It started from a spatial concentration of this fruit production in this valley, albeit it is also known in many other parts of the Alps. By applying a specific strategy to increase the valorization of the plant and initiatives to identify the local population with the product and related cultural aspects, the former 6,000 cornel trees (up to 2000) were extended to a number of about 14,000 trees (by 2012; Schuh 2012). Due to the holistic approach driving this initiative the regional activities received the European Award of "Destination of Excellence" in 2007, and several other awards for innovative regional action. It contributed in particular to fostering efforts towards "sustainable tourism", including a high share of agritourism activities. The core role of sustainable tourism in the region is highlighted in the following Figure which indicates both the economic and emotional valorisation of the product as key components for achieving pathways that are conducive to sustainable regional development.

\section{Discussion and Conclusions}

Rural tourism as a specific driver for diversification opportunities is hence visible in these examples focusing on flowers or plants as main attractions of particular "regional appeal" and trigger for agritourism activities. Like in the case of rhododendron in China, many initiatives in European mountain regions are characterized by spe- cific plants that underpin a particular heritage value and identity for the area. As Heneghan et al. (2016) argue rural tourism can be a source of economic benefits due to significant potentials "to revitalise local economies, provide job opportunities for farm household members and enhance the quality of life of rural communities" (p. 1). The many aspects involved in establishing an agritourism activity, that links agricultural and tourism activities in a beneficial way (Figure 2), implies a comprehensive analysis of options, natural and cultural heritage, regional specificity, market analysis and development, creative thinking and linking local and regional to large-scale spatial inter-relations. As the tourism market is particularly alert at nurturing heritage features (LaPan and Barbieri 2013; Lo et al. 2017) and local specificity, the presented examples on flower blossoming and plants production are particularly instructive in their different regional contexts.

Key lessons arising from the comparative analysis of agritourism approaches built on plants and flowers as core elements in TDI relate to:

- The unique natural and cultural resources of PSA which builds upon the PSA's original image, while the tourist destination image (TDI) of those areas mainly depends upon the perceived image of tourists to the area. To achieve benefits for all stakeholders of such an area, it is pivotal to elaborate local agritourism opportunities around suitable TDI of this area. This necessitates a careful balance between preservation and agritourist activities.

- The presented cases reflect the different regional contexts and testify different types of approaches. They

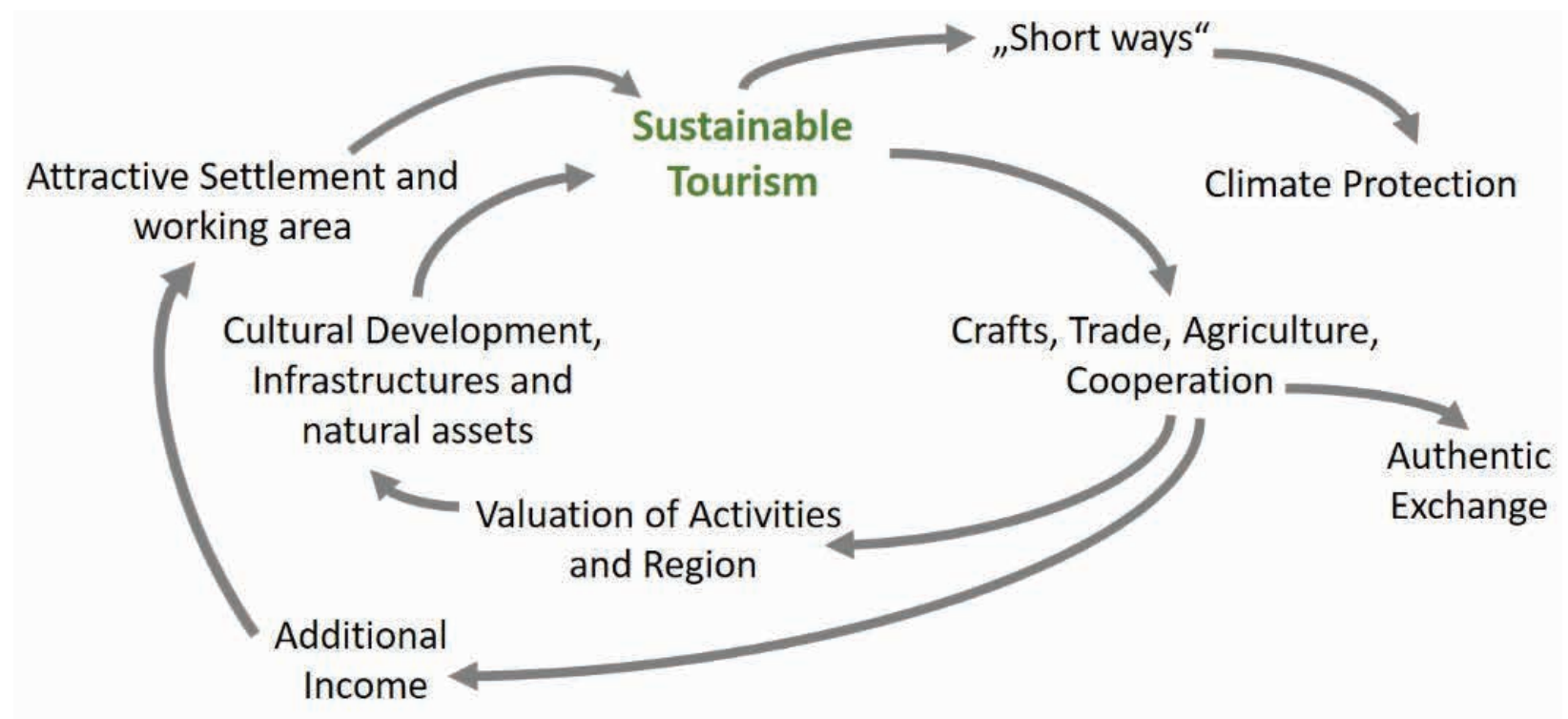

Figure 2: Influences on and effects of Sustainable Tourism framework

Source: Regionalplanungsgemeinschaft Pielachtal 2008, 19 (translated by author) 
indicate the wide scope of relevant actions and the focus on place-adapted strategies.

- The analyzed cases underpin main challenges and success factors, in particular, the short period of attractive season of the plants and flowers, the efforts to extend agritourism activities to low seasons, the links to be tightened between actors of different sectors, the limitations of tourism capacity in core zones, and the need for shaping accompanying infrastructure and service development.

The complementary function between agritourism and the PSA's tourist destination image includes, but is not limited to, the following aspects:

- TDI promotes the transformation of traditional agricultural economy to new types, while agritourism expands the PSA's tourism destination image and might contribute to break the seasonal barriers to tourism.
- Building on place-based strengths and opportunities, it promotes the service image of the preservation area, and might enhance the transportation facilities and the "images" of the park area.

- Highlighting "iconic" plants or activities centred around a leading regional product is crucial to explain distinction to other regions which is often sustained through designation as PSA.

- A specific task is due to the efforts to transmit "scenic appeal" of plants and landscape features to tourists.

- Agritourism activities have to seek approaches that foster experiences through recreation on active farms by achieving memorable encounters, which are linked to the place, relevant for tourists and might be experienced in a flexible way (Barbieri et al. 2016).

- These farm stay experiences are particularly influenced by the "role of historically structured socio-cultural forces and modes of engagement of persons with the atmosphere” (Brown et al. 2019, 5).

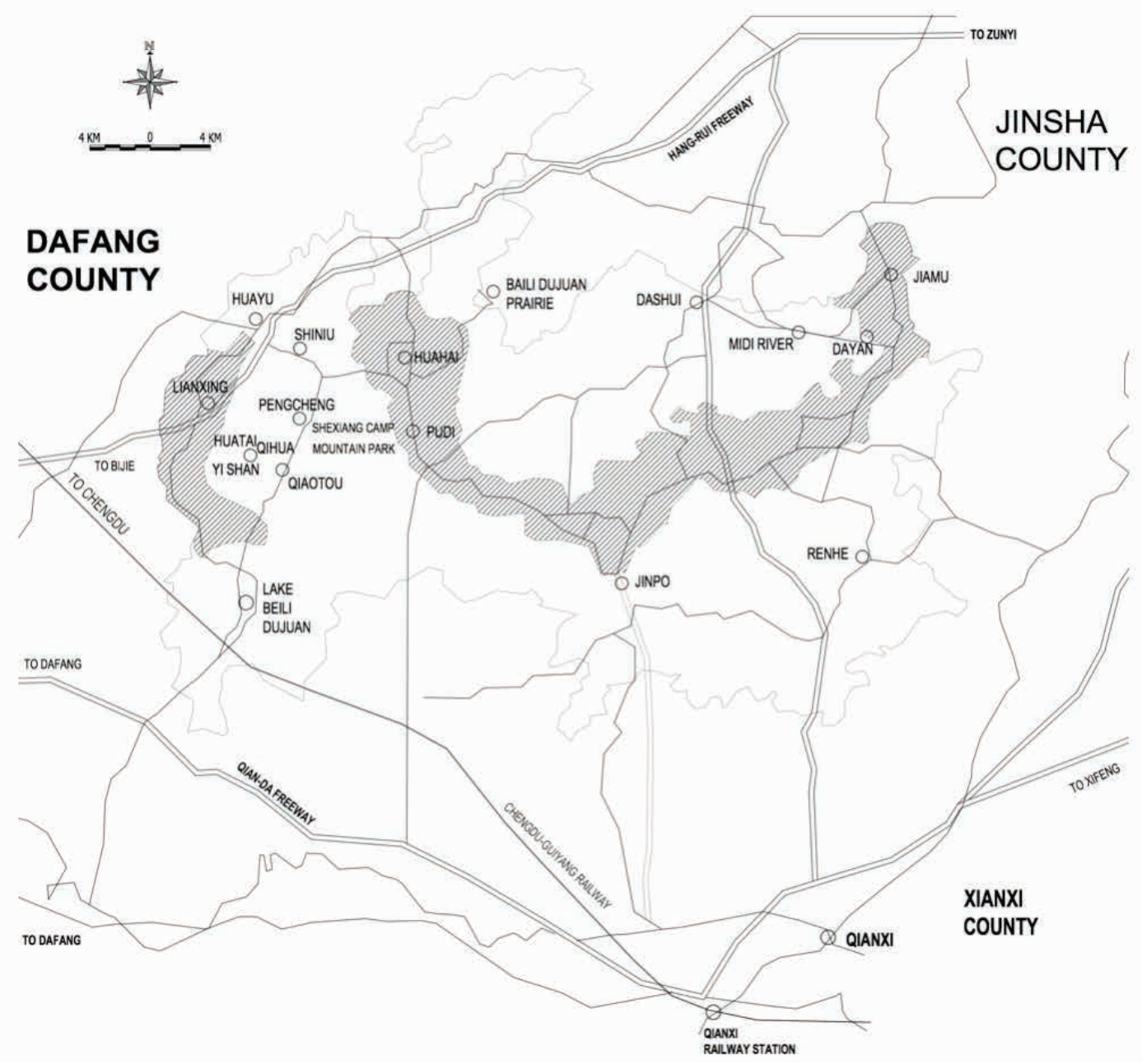

Figure 3: Location of Baili Dujuan Scenic Area in province Guizhou 


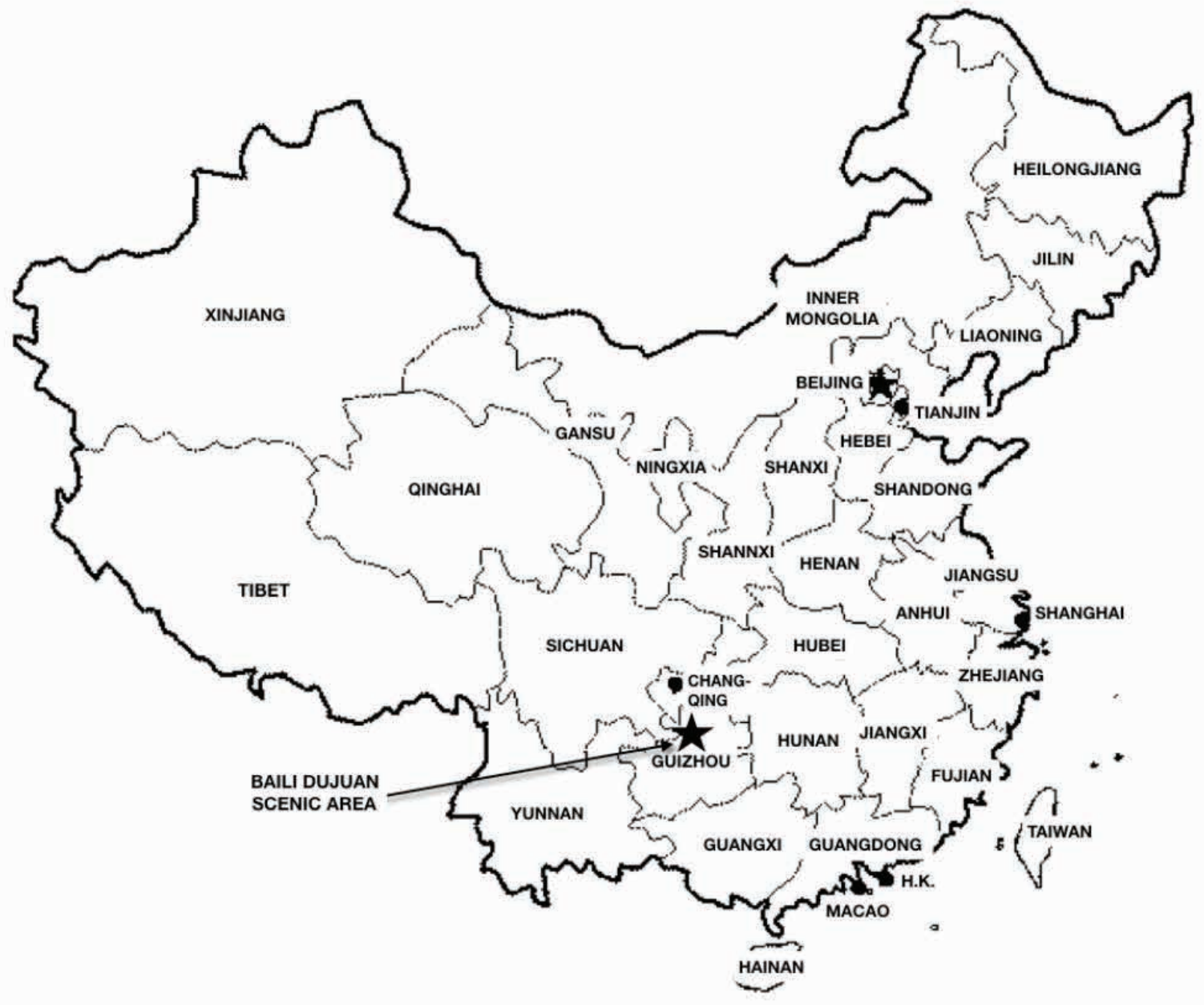

Figure 4: Location of Baili Dujuan Scenic Area in China.

- Practice elaboration is a sensitive issue and limits ability of transfer of theoretical considerations (Slocum and Curtis 2018).

Even if China's management system is different from that of Europe, the development of community initiatives to nurture the specific local assets for agritourism development is crucial for strategy building for TDI and agritourism preferences in all contexts. Despite its dependence on place "origin", processes of implementation relate to similar elements and general lessons can be transferred from regional activities in PSA. In particular, placing botanical assets in the centre of regional strategies underlines the valuation and potential of place-based resources in agritourism.

Conflict of interest: Authors declare no conflict of interest.

\section{References}

[1] Baloglua S. and McCleary W.K., A model of destination image formation. Annals of Tourism Research, 1999, 26(4), 868-897

[2] Barbieri C., Assessing the sustainability of agritourism in the US: A comparison between agritourism and other farm entrepreneurial ventures, Journal of Sustainable Tourism, 2013, 21(2), 252-270

[3] Barbieri C., Mahoney E. and Butler L., Understanding the nature and extent of farm and ranch diversification in North America, Rural Sociology, 2008, 73(2), 205-229

[4] Barbieri C., Xu S., Gil Arroyo C. and Rozier Rich S., Agritourism, farm visit, or...? A branding assessment for recreation on farms, Journal of Travel Research, 2016, 55(8), 1094-1108

[5] Brown S.D., Kanyeredzi A., McGrath L., Reavey P. and Tucker I., Affect theory and the concept of atmosphere, Distinktion: Journal of Social Theory, 2019, 20(1), 5-24

[6] Copus A., Shucksmith M., Dax T. and Meredith D., Cohesion Policy for rural areas after 2013, A rationale derived from the EDORA project (European Development Opportunities in Rural Areas) ESPON 2013 Project 2013/1/2, Studies in 
Agricultural Economics, 2011, 113, 121-132. http://dx.doi. org/10.7896/j.1113

[7] Dorocki S., Rachwal T., Szymańska A.I. and Zdon-Korzeniowska M., Spatial Conditions for Agritourism Development on the Example of Poland and France, Current Issues of Tourism Research, 2012, 15(2), 20-29

[8] Embacher H., Marketing for Agri-tourism in Austria: Strategy and realization in a highly developed tourist destination, Journal of Sustainable Tourism, 1994, 2(1-2), 61-76. https:// doi.org/10.1080/09669589409510684

[9] Ermann U., Langthaler E., Penker M. and Schermer M., Agro-food studies. Eine Einführung, Böhlau Verlag, Weimar and Wien, 2018

[10] Fabio M.S., Agritourism for Rural Development in Italy, Evolution, Situation and Perspectives, British Journal of Economics, Management \& Trade, 2013, 3(3), 186-200

[11] FarmStayPlanet, The Lavender Fields of Provence, France in 2019: Where to Go, When to Go \& Where to Stay, 2018

[12] Fondation Grand Paradis, Paradisia Alpine Botanical Garden. Cogne, 2018, https://www.grand-paradis.it/en/ natural-areas/paradisia-alpine-botanical-garden

[13] Gao J., Barbieri C. and Valdivia C., Agricultural landscape preferences: Implications for agritourism development, Journal of Travel Research, 2014, 53(3), 366-379

[14] Gil Arroyo C., Barbieri C. and Rozier Rich S., Defining agritourism: A comparative study of stakeholders' perceptions in Missouri and North Carolina, Tourism Management, 2013, 37, 39-47

[15] Griffero T., Atmospheres: Aesthetics of emotional spaces, Ashgate, Farnham, UK, 2014

[16] Growing Rural Tourism Conference, Be the Change, Conference (11-13 February 2019, Alberta, Canada), http:// growingruraltourism.ca/

[17] Guo Q. and Dong J., A study on Pricing Models of Entrance Tickets for Resource-Preserved Tourist Attractions, Journal of Tourism, 2010, 25(08), 72-77

[18] Hall D., Rural tourism development in southeastern Europe: transition and the search for sustainability, International Journal of Tourism Research, 2004, 6(3), 165-176, https://doi. org/10.1002/jtr.482

[19] Heneghan M., Caslin B., Ryan M. and O’Donoghue C., Rural Tourism, Teagasc, Rural Economy \& Development Programme, Athenry, 2016, https://www.teagasc.ie/media/website/ publications/2016/Rural-Tourism-Booklet.pdf

[20] Khamung R., A Study of Cultural Heritage and Sustainable Agriculture Conservation as a Means to Develop Rural Farms as Agritourism Destinations, Silpakorn University Journal of Social Sciences, Humanities, and Arts, 2015, 15(3), 1-35

[21] LaPan C. and Barbieri C., The role of agritourism in heritage preservation, Current Issues in Tourism, 2013, 17(8), DOI: 10.1080/13683500.2013.849667

[22] Li P., Development of Agritourism Resources in PovertyStricken Areas and Ways of Increasing Farmers' Income, Agricultural Economy, 2017, 9, 76-78

[23] Lin H. and Qiao H., An Empirical Study on the Interactive Development of British Tourism and Agriculture from the Perspective of Industrial Integration, World Agriculture, 2017, 3,143-147

[24] Lo M.-C., Mohamed A.A., Chin C.-H. and Ramayah T., The Impact of Natural Resources, Cultural Heritage, and Special
Events on Tourism Destination Competitiveness: The Moderating Role of Community Support, International Journal of Business and Society, 2017, 18(S4), 763-774

[25] Lu D., Liu Y., Lai I. and Yang L., Awe: An Important Emotional experience in Sustainable Tourism, Sustainability, 2017, 9 , 2189, DOI: $10.3390 /$ su9122189

[26] Lupi C., Giaccio V., Mastronardi L.,Giannelli A. and Scardera A., Exploring the features of agritourism and its contribution to rural development in Italy, Land Use Policy, 2017, 64, 383-390, https://doi.org/10.1016/j.landusepol.2017.03.002

[27] LY.com., Beili Dujuan Scenic Area, 2017, https://www. ly.com/go/scenery/113/1130000009622.html

[28] McGehee N.G., An Agritourism Systems Model: A Weberian Perspective, Journal of Sustainable Tourism, 2007, 15(2), 111-124, DOI: 10.2167/jost634.0

[29] McMahon F., Rural and Agri-Tourism in Central and Eastern Europe, In: Richards G. (Ed.), Tourism in Central and Eastern Europe: Educating for Quality, Tilburg University Press, Tilburg (NL), 1996, 175-182

[30] National Tourism Bureau, National Standards for the Inspection of Industrial and Agricultural Tourism Demonstration Points (Trial), 2002

[31] Pike A., Origination, The Geographies of Brands and Branding, Wiley Blackwell, Chichester, 2015

[32] Pike S., Tourism destination branding complexity, Journal of Product \& Brand Management, 2005, 14(4), 258-9, https:// doi.org/10.1108/10610420510609267

[33] Potočnik-Slavič I. and Schmitz S., Farm Tourism across Europe, European Countryside, 2013, 5(4), 265-274, DOI: 10.2478/euco-2013-0017

[34] Pruckner G., Agritourism and landscape conservation program in Austria, In: OECD (Ed.), Multifunctionality in Agriculture: What Roles for Private Initiatives? OECD Publishing, Paris, 2005, 57-62

[35] Regionalplanungsgemeinschaft Pielachtal, Nachhaltigkeit Pielachtal, Das Dirndltal. Kirchberg/Pielach, 2008

[36] RoseFestivalKazanlak.com, Bulgaria's Rose Valley and Rosa Damascena - A brief History, Kazanlak, 2018, https://www. rosefestivalkazanlak.com/rosa-damascena-importance-bulgarian-rose-valley/

[37] Santucci F.M., Agritourism for Rural Development in Italy, Evolution, Situation and Perspectives, British Journal of Economics, Management \& Trade, 2013, 3(3), 186-200

[38] Schuh K., Kornelkirsche: Die Dirndl aus dem Pielachtal. 29.07.2012, Die Presse, Wien

[39] Selby M. and Morgan J.N., Reconstructing place image: A case study of its role in destination market research, Tourism Management, 1996, 17(4), 287-294

[40] Sidali K.L., Kastenholz E. and Bianchi R., Food tourism, niche markets and products in rural tourism: Combining the intimacy model and the experience economy as a rural development strategy, Journal of Sustainable Tourism, 2015, 23, 1179-1197

[41] Shucksmith M., Re-imagining the rural: From rural idyll to Good Countryside, Journal of Rural Studies, 2018, 59 , 163-172, http://dx.doi.org/10.1016/j.jrurstud.2016.07.019

[42] Slocum S.L. and Curtis K.R., Food and agricultural tourism theory and best practice, Routledge, London, 2018

[43] Shao Q., China Travel Dictionary, Shanghai Dictionary Publishing House, Shanghai, 2012, 379 
[44] Streifeneder T., Agriculture first: Assessing European policies and scientific typologies to define authentic agritourism and differentiate it from countryside tourism, Tourism Management Perspectives, 2016, 20, 251-264, https://doi. org/10.1016/j.tmp.2016.10.003

[45] Sznajder M., Przezbórska L. and Scrimgeour F., Agritourism, CAB International, Wallingford, 2009

[46] The Fondation Grand Paradis, Gran Paradiso case study, 2018, https://www.grand-paradis.it/en

[47] Tourist Administration of Beili Dujuan District, Statistical Table of Accommodation Facilities in Beili Dujuan District, 2018, http://bldj.bijie.gov.cn/lyfw/lygl/hhyl/czxy/ bgjd/233033.shtml

[48] Wang L., Cheng S., Zhong L., Mu S., Dhruba B.G.C. and Ren G., Rural Tourism Development in China: Principles, Models and the Future, Journal of Mountain Science, 2013, 10(1), 116-129, DOI: 10.1007/S11629-013-2501-3

[49] Wang L. and Yotsumoto Y., Conflict in tourism development in rural China, Tourism Management, 2019, 70, 188-200, https://doi.org/10.1016/j.tourman.2018.08.012

[50] Wang Z. and Xu W., Role of Rapeseed Flowers in Rural Tourism, Shanxi Architecture, 2014, 40(11), 229-230

[51] Wen C., Li L., Xu W. and Zhang Q., An overview of tourism destination image research, Geography and Geographic Information Sciences, 2009, v.2506, 105-109

[52] Xu D., Research on brand positioning of resource-conserving tourist attractions, Financial economics, 2008, 8, 31-32

[53] Zhang L., Development Strategies of Rapeseed-Enjoying Tourism Experience Products in Wuyuan, Jiangxi, National Circulation Economy, 2017, 10, 47-48 